\title{
Zirconium Zr 89 Anti-EGFR Monoclonal Antibody ABT-806
}

National Cancer Institute

\section{Source}

National Cancer Institute. Zirconium Zr 89 Anti-EGFR Monoclonal Antibody ABT-806. NCI

Thesaurus. Code C148163.

A radioimmunoconjug ate composed of $\mathrm{ABT}-806$, a humanized immunog lobulin G1 (IgG1) monoclonal antibody directed against the epidermal growth factor receptor (EGFR), labeled with the radioisotope zirconium $\mathrm{Zr}$ 89, with potential use as an imaging agent upon positron emission tomography (PET). Upon administration of zirconium $\mathrm{Zr}$ 89 anti-EGFR monoclonal antibody ABT-806, the antibody moiety binds to a specific EGFR epitope of either the wild-type or the variant III mutant (EGFRvIII; de2-7 EGFR; DEGFR) on tumor cells. Upon PET imaging, EGFR-expressing tumor cells can be visualized and assessed. This may result in the quantification of EGFR-expressing tumor cells, an assessment of the expected response to treatment with ABT-806 and the selection of patients that would respond to ABT-806. ABT-806 is the humanized version of chimeric monoclonal antibody 806. EGFR, a receptor tyrosine kinase overexpressed on the cell surfaces of many tumor cell types, plays a key role in tumor cell proliferation. 